\title{
PREDICTION OF GLUCOSE LEVEL IN DIABETICS WITH SUPPORT VECTOR REGRESSION
}

\author{
Devi Wulandari1 ${ }^{*}$; Agus Subekti ${ }^{1 \#, 2}$ \\ Masters in Computer Science \\ 1,2 Sekolah Tinggi Manajemen Informatika dan Komputer Nusa Mandiri \\ ${ }^{1}$ www.nusamandiri.ac.id \\ 1dw91325@gmail.com; 1\#agus@nusamandiri.ac.id
}

${ }^{2}$ Pusat Penelitian Informatika LIPI

${ }^{2}$ Lembaga Ilmu Pengetahuan Indonesia (LIPI)

2http://informatika.lipi.go.id/

2agus.subekti@lipi.go.id

* Corresponding Author

\begin{abstract}
One of the common diabetes factors that people hear is that they consume too much or often consume sweet foods or drinks so that blood sugar in the human body increases. The times and increasingly sophisticated technology make it easier for someone to be able to predict a disease such as diabetes with machine learning techniques. Therefore, from the existing problems, a machine learning technique will be made in predicting glucose levels in diabetics. The aim is to predict glucose levels in diabetics and find the best algorithm from several comparison algorithms. The results of the experiments carried out by the support vector regression algorithm have a lower mean squared error value of 28.9480 compared to other comparative algorithms and visualize the error classification seen that Instance no 47 has a prediction of the highest plasma glucose value of 189.2305 .
\end{abstract}

Keywords: Diabetes, Glucose Level, Support Vector Regression

Abstrak-Salah satu faktor penyakit diabetes yang
biasa di dengar oleh masyarakat yaitu karena
terlalu banyak atau seringnya mengkonsumsi
makanan atau minuman manis sehingga gula darah
pada tubuh manusia meningkat. Perkembangan
zaman serta teknologi yang semakin canggih
mempermudah seseorang untuk dapat memprediksi
suatu penyakit salah satunya diabetes dengan
teknik machine learning. Oleh karena itu, dari
permasalahan yang ada akan dibuatkan teknik
machine learning prediksi level glukosa pada
penderita diabetes. Tujuannya adalah untuk
memprediksi level glukosa pada penderita diabetes
dan menemukan algoritma terbaik dari beberapa
algoritma pembanding. Hasil dari eksperimen yang dilakukan algoritma support vector regression memiliki nilai root mean squared arror lebih rendah yaitu 28,9480 dibanding dengan algoritma yang pembanding yang lain dan visualize clasifier error dilihat bahwa Instance no 47memiliki prediksi nilai plasma glukosa tertinggi yaitu 189,2305.

Kata Kunci: Diabetes, Level Glukosa, Support Vector Regression

\section{INTRODUCTION}

Diabetes is a disease that we have been very common to hear and meet. Some factors that cause diabetes are emerging such as genetic factors, weight loss, food and bad habits in daily life (Soumya \& Srilatha, 2011). Machine learning with the development of algorithms and techniques (Kaur \& Kumari, 2018) with Artificial Intelligence (AI) intelligence can identify and understand each data input so that it can predict results and make decisions (Sun, 2013).

One of the common diabetic factors that people hear is that they consume too much or often eat sweet foods or drinks so that blood sugar in the human body increases (Anggraini, 2019). At this time blood sugar checks to determine the level of sugar in the human body have often been done in health centers or hospitals. However, the development of the times and technology have a lot of researchers doing research on diabetes with machine learning techniques.

Neural Network models provide a suitable construction for glucose prediction in which many factors influence and are indicators of future glycemic trends (Pappada et al., 2011)(Alloghani et al., 2019). Given the increasing use of CGM technology, NNMs trained using CGM data have 
become the focus of investigations recently (Pappada et al., 2011). Meanwhile according to diabetes mellitus is a global problem (Robertson et al., 2011) that continues to increase. However, it has been shown that the set is good Blood glucose levels (BGL) (Robertson et al., 2011). Related complications and expensive costs can be reduced significantly. In this learning example, Elman repeated Artificial Neural Networks (ANNs) used to make BGL predictions (Sandham et al., 2011) based on BGL history (Al-Khasawneh \& Hijazi, 2014), food intake, and insulin.

This research only discusses the prediction of diabetes in female patients with 8 (eight) independent variables or attributes, namely pregnancy, plasma glucose, diastolic blood pressure, triceps skin fold, serum insulin, bodymask index, diabetes pedigree and age (Sarojini et al., 2009) and 1 dependent variable namely the diabetes and non-diabetes class label. Then, plasma glucose variable is used as a factor that influences whether or not patients are tested using a regression method, namely support vector regression, Neural Network, Random Forest, KNearest Neighbors (KNN).

The purpose of this study is to predict glucose levels in diabetics with the research methodology used in this research is to use the Knowledge Discovery in Database (KDD) (Kavakiotis et al., 2017).

\section{MATERIALS AND METHODS}

Lack of insulin (insulin resistance) will cause diabetes. The main energy source in the human body is glucose which is used for all metabolic processes. The regulation of glucose movement in the body is regulated by hormones from the pancreas. As a result of diabetes affects the body's metabolic disorders, and complications arising from impaired kidney function, impaired eye function, disorders of blood vessels, and other related complications.. The complications that occur as a result of diabetes will affect the body's metabolism. This diabetic disease often impacts on blindness, causes heart disease, stroke, kidney failure, and so forth. Some things from microvascular which are attenuated into complications by diabetes, including nephropathy, retinopathy, and neuropathy, as well as atherosclerosis and stroke (Soumya \& Srilatha, 2011).

Blood sugar or glucose is the amount of glucose that can be found in the bloodstream of humans which generally have units of $\mathrm{mg} /$ $\mathrm{dL}$. The body naturally regulates blood sugar levels with the help of the hormone insulin produced by pancreatic beta cells as part of the body's
homeostasis(Belinda, 2019). Blood sugar levels can change at any time, especially before and after eating and when the body will rest or sleep. This happens because after eating, the digestive system will begin to break down carbohydrates into sugar or glucose so that it can be absorbed by the body and processed into energy(Belinda, 2019)

Support Vector Machine (SVM) is a vectorbased vector model that requires a text to be converted into a vector before it is used for classification. The key idea of SVM is to find (Waila et al., 2012) the maximum decision surface (hyperlane) of each data point to conduct training machines supported by vectors or commonly called SVM that require a very large Quadratic Programming (QP) solution (Saputra et al., 2016). Regression is a process that can make a prediction of various patterns that have been previously formed as a data model. The purpose of regression is to create a new variable that represents a representation of data development in the future. WEKA supports the regression process and this is facilitated with a simple user interface or user experience.

In this study, the type used is Absolute Experiment where in this research predict glucose levels in diabetics with support vector regression with the population in this study are diabetics and the sample used in this study is the data of female patients with age ranging from 21 years old who has diabetes.

The dataset for this study is the Indian Pima population taken from repositories https://archive.ics.uci.edu/ml/datasets/diabetes which contains data on female patients with a minimum age of 21 years with a total of 8 attributes and 768 instances and classified into 2 (two) classes, namely diabetes and non-diabetes.

Table 1 Diabetes of Indian Pima dataset

\begin{tabular}{cccc}
\hline No. Attribute & Attribute & $\begin{array}{c}\text { Variable } \\
\text { Type }\end{array}$ & Distance \\
\hline A1 & Pregnancy & Integer & $0-17$ \\
\hline A2 & Plasma Glucose & Real & $0-199$ \\
\hline A3 & $\begin{array}{c}\text { Diastolic Blood } \\
\text { Pressure }\end{array}$ & Real & $0-122$ \\
\hline A4 & $\begin{array}{c}\text { Triceps Skin } \\
\text { Fold }\end{array}$ & Real & $0-99$ \\
\hline A5 & Serum Insulin & Real & $0-846$ \\
\hline A6 & Body Mass Index & Real & $0-67,1$ \\
\hline A7 & $\begin{array}{c}\text { Diabetes } \\
\text { Pedigree }\end{array}$ & Real & $\begin{array}{l}0,078- \\
2,42\end{array}$ \\
\hline A8 & Age & Integer & $\begin{array}{l}21-81 \\
1= \\
\text { Class }\end{array}$ \\
& & Binary & $\begin{array}{l}1= \\
\text { diabetes } \\
0= \\
\text { negative } \\
\text { diabetes }\end{array}$ \\
\hline
\end{tabular}

Sources:(Kaur \& Kumari, 2018) 
In this study the data collection method used is secondary data where the main data obtained from the UCI machine learning repository with a total of 768 data classified into 2 (two) classes, namely diabetes and non-diabetes with 8 (eight) risk factors namely number of pregnancies, glucose plasma, blood pressure, skinfold thickness, insulin, weight, diabetes pedigree and age.

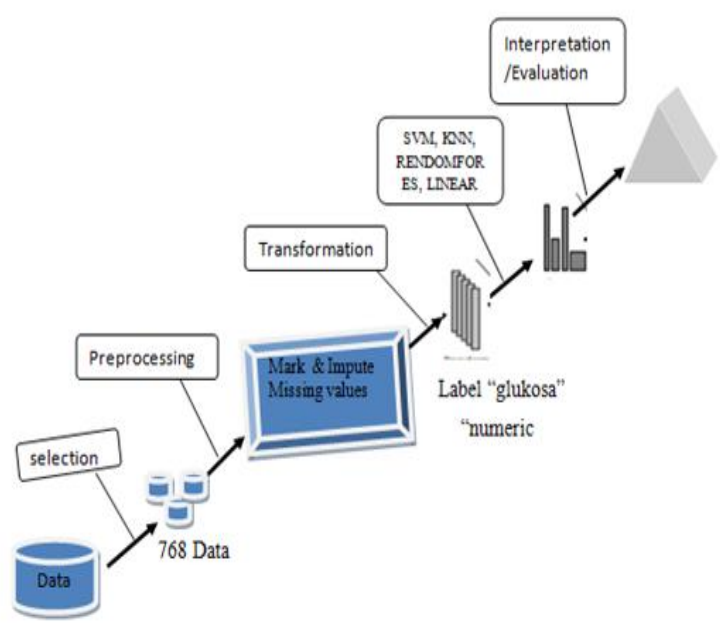

Sources: (Wulandari \& Subekti, 2019)

Figure 1 Steps in the Knowledge Discovery Process in Database (KDD)

\section{RESULTS AND DISCUSSION}

Data taken through the Pima Indian dataset contained in the UCI repository with 768 instances ( 8 attributes and 1 label), here are some original diabetes datasets:

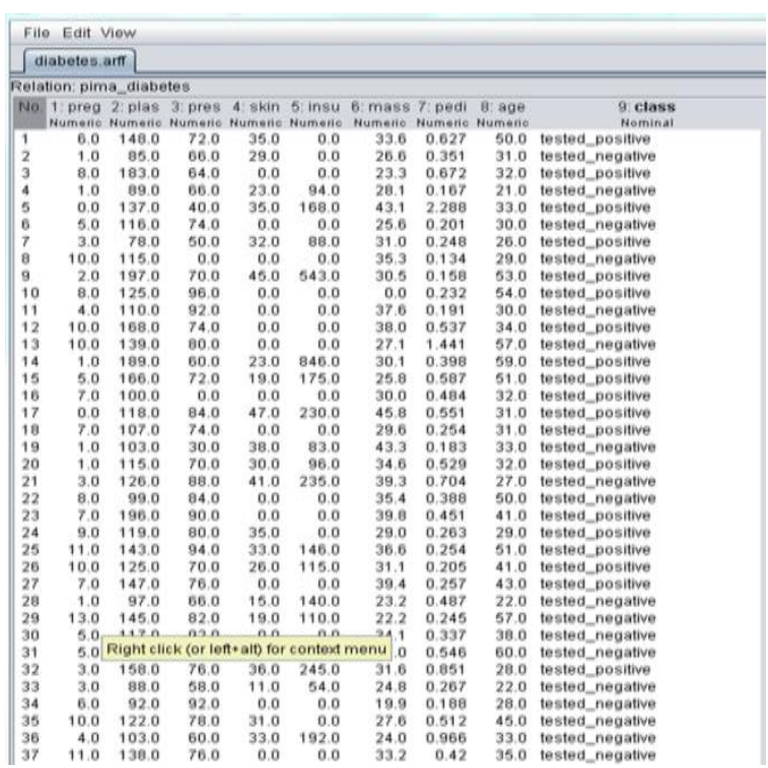

Sources: (Kahn, 1994)

\section{Figure 2 Indian Pima Diabetes dataset}

Can be seen that in some of the diabetes data that has not been processed in the picture above there are some data with a value of 0 which means that the data is missing values so that this data will go through preprocessing so that there is no data with a value of 0 or missing values .

Based on the diabetes dataset above, there are some data with 0 values or missing values, so it needs to be processed so that there are no more data with missing values.

One problem that often occurs in research is missing data or commonly known as missing data (Santoso. S, 2012). Missing data is information that is not available for an object. There are several ways that can be done to deal with missing data(Mukarromah et al., 2015) such as: Listwise deletion, Pairwise deletion and Imputation. Listwise deletion is to delete cases (objects) that contain missing data. Pairwise deletion is by removing missing data, so that only the available values are analyzed. Imputation is to fill in missing data with possible values based on information available on the data.

After completing the preprocessing stage and changing the glucose level into a major and influential factor, the results obtained from this study by conducting several algorithm experiments, namely:

Table 2 Summary of Diabetes Positive Data expected in a Support Vector Regression

\begin{tabular}{lcc}
\hline \multicolumn{1}{c}{ SVM } & $\mathbf{N}$ & TN \\
\hline $\begin{array}{l}\text { Correlation } \\
\text { coefficient }\end{array}$ & 0.241 & 0.2413 \\
\hline Mean absolute error & 23,8534 & 23,8554 \\
\hline $\begin{array}{l}\text { Root mean squared } \\
\text { error }\end{array}$ & 28,9548 & 28,9480 \\
\hline $\begin{array}{l}\text { Relative absolute } \\
\text { error }\end{array}$ & $95,5132 \%$ & $95,5210 \%$ \\
\hline $\begin{array}{l}\text { Root relative } \\
\text { squared error }\end{array}$ & $98,2801 \%$ & $98,2569 \%$ \\
\hline $\begin{array}{l}\text { Total } \\
\text { Number of }\end{array}$ & 268 & 268 \\
Instances & & \\
\hline
\end{tabular}

Sources: (Wulandari \& Subekti, 2019)

Seen from table 2 diabetes data results using the SVM algorithm with 2 (two) experiments, namely by normalizing the data and without normalizing. It is seen that the lowest Root Mean Squared Error (RMSE) value is found in experiments with un normalized data with a value of 28.9460 . 


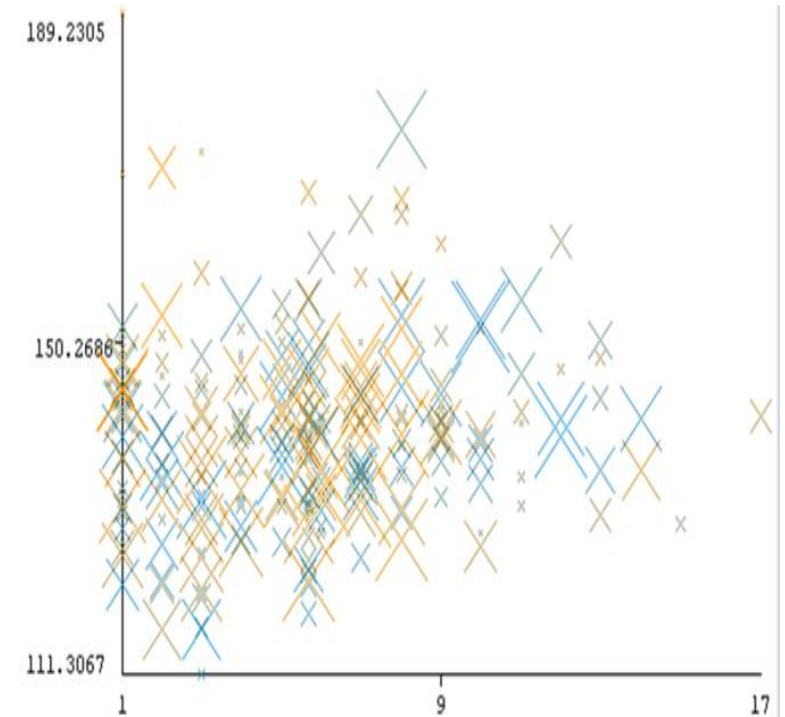

Sources: (Wulandari \& Subekti, 2019)

Figure 3: Plot prediction of plasma glucose in pregnancy

Figure 3 shows the plot or visualize error class between $\quad \mathrm{X}$ variable, namely preggnancy (pregnancy) and $\mathrm{Y}$ variable, which is prediction of plasma glucose with values ranging from 1 to 17 and $\mathrm{x}$ values ranging from 111.3067 to 189.2305 , indicating that there are more errors in pregnancy between 1-9 with a plasma predictive value of $189,2305 \mathrm{mg} . \mathrm{dl}$.

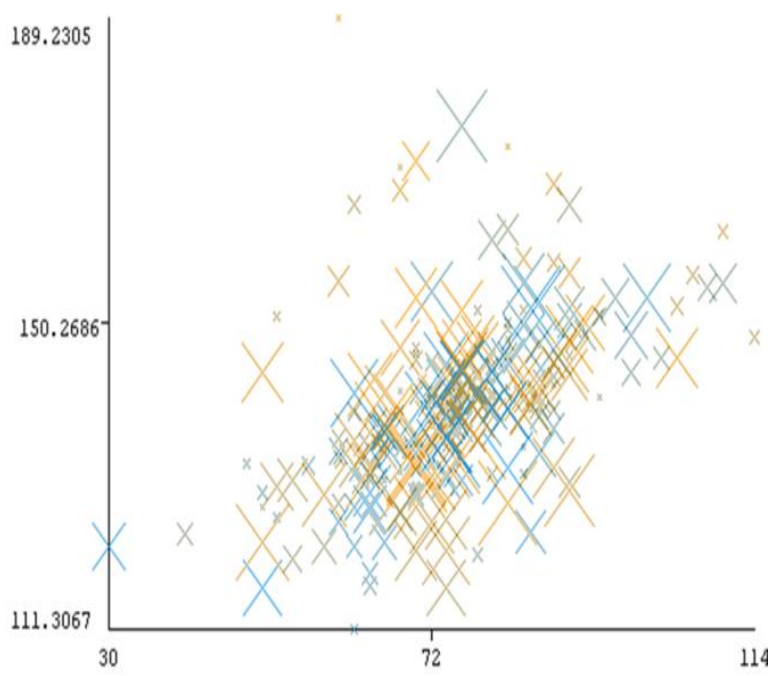

Sources: (Wulandari \& Subekti, 2019)

Figure 4 Plot prediction of plasma glucose in blood pressure

Figure 4 shows the plot or visualize error classifier between variable $\mathrm{X}$, namely blood pressure (blood pressure) with a minimum value of $30 \mathrm{~mm} \mathrm{hg}$ and a maximum of $114 \mathrm{~mm} \mathrm{hg}$ and $\mathrm{Y}$ variable, prediction of plasma glucose 111.3067 to 189.2305.

Table 3 Results of Positive Diabetes Data with Neural Network

\begin{tabular}{lcc}
\hline Neural Network & $\mathbf{N}$ & $\mathbf{T N}$ \\
\hline $\begin{array}{l}\text { Correlation } \\
\text { coefficient }\end{array}$ & 0.1404 & 0.1404 \\
\hline $\begin{array}{l}\text { Mean absolute } \\
\text { error }\end{array}$ & 28,7590 & 28,7590 \\
$\begin{array}{l}\text { Root mean } \\
\text { squared error }\end{array}$ & 35,5662 & 35,5662 \\
\hline $\begin{array}{l}\text { Relative } \\
\text { absolute error }\end{array}$ & $115,1565 \%$ & $115,1565 \%$ \\
\hline $\begin{array}{l}\text { Root relative } \\
\text { squared error }\end{array}$ & $120,7207 \%$ & $120,7207 \%$ \\
\hline $\begin{array}{l}\text { Total } \\
\text { Number of } \\
\text { Instances }\end{array}$ & 268 & 268 \\
\hline Sources: (Wulandari \& Subekti, 2019) &
\end{tabular}

Based on table 3 the results of non-diabetic data using Neural Network algorithm with 2 (two) experiments, namely with data normalization and without normalization. It was seen that the lowest Root Mean Squared Error (RMSE) value was found in experiments with normalized data and without normalization with a value of 35.5662 .

Table 4 Results of Positive Diabetes Data with Random Forest

\begin{tabular}{lcc}
\hline Random Forest & $\mathbf{N}$ & TN \\
\hline $\begin{array}{l}\text { Correlation } \\
\text { coefficient }\end{array}$ & 0.2818 & 0.2953 \\
$\begin{array}{l}\text { Mean absolute } \\
\text { error }\end{array}$ & 23,4076 & 23,3917 \\
\hline $\begin{array}{l}\text { Root mean } \\
\text { squared error }\end{array}$ & 28,5091 & 28,3303 \\
\hline $\begin{array}{l}\text { Relative absolute } \\
\text { error }\end{array}$ & $93,7285 \%$ & $93,6645 \%$ \\
\hline $\begin{array}{l}\text { Root relative } \\
\text { squared error }\end{array}$ & $96,7673 \%$ & $96,1604 \%$ \\
\hline $\begin{array}{l}\text { Total } \\
\text { Number of } \\
\text { Instances }\end{array}$ & 268 & 268 \\
\hline Sources: (Wulandari \& Subekti, 2019) & \\
\hline
\end{tabular}

Table 4 shows the results of positive diabetes data using the random forest algorithm with 2 (two) experiments, namely data normalization and without normalization. It is seen that the lowest Root Mean Squared Error (RMSE) value is in experiments with data without normalization with a value of 28.3303 . 
Table 5 Results of Positive Diabetes Data with KNN

\begin{tabular}{lcc}
\multicolumn{1}{c}{ KNN } & $\mathbf{N}$ & $\mathbf{T N}$ \\
\hline $\begin{array}{l}\text { Correlation } \\
\text { coefficient }\end{array}$ & 0.1497 & 0.1497 \\
\hline $\begin{array}{l}\text { Mean absolute } \\
\text { error }\end{array}$ & 24,2150 & 24,2150 \\
\hline $\begin{array}{l}\text { Root mean } \\
\text { squared error }\end{array}$ & 29,3635 & 29,3635 \\
\hline $\begin{array}{l}\text { Relative absolute } \\
\text { error }\end{array}$ & $96,9613 \%$ & $96,9613 \%$ \\
\hline $\begin{array}{l}\text { Root relative } \\
\text { squared error }\end{array}$ & $99,6671 \%$ & $99,6671 \%$ \\
$\begin{array}{l}\text { Total } \\
\begin{array}{l}\text { Number of } \\
\text { Instances }\end{array}\end{array}$ & 2688 \\
\hline Sources: (Wulandari \& Subekti, 2019) &
\end{tabular}

Based on table 5 the results of diabetes positive data using the k-Nearest neighbors (KNN) algorithm with 2 (two) experiments, namely data normalization and without normalization. It is seen that the lowest Root Mean Squared Error (RMSE) value is found in experiments with normalized data and without normalization with a value of 23.33496.

\section{CONCLUSION}

Based on the results of research on the prediction of glucose levels in diabetics it can be concluded that the Support Vector Machine Algorithm is better because it has a lower root mean squared error value of 28.9480 compared to comparison algorithms such as Neural Network, Rendom Forest, and K-Nearest Neigbors ( KNN). In the plot or visualize error class, it is seen that Instance no. 47 has the highest prediction of the plasma glucose value, 189.2305.

\section{REFERENSI}

Al-Khasawneh, A., \& Hijazi, H. (2014). A Predictive E-Health Information System: Diagnosing Diabetes Mellitus Using Neural Network Based Decision Support System. International Journal of Decision Support System Technology, 6(4), 31-48. https://doi.org/10.4018/ijdsst.2014100103

Alloghani, M., Aljaaf, A., Hussain, A., Baker, T., Mustafina, J., Al-Jumeily, D., \& Khalaf, M. (2019). Implementation of machine learning algorithms to create diabetic patient readmission profiles. BMC Medical Informatics and Decision Making, 19(Suppl 9), 253. https://doi.org/10.1186/s12911-019-0990-x
Anggraini, A. (2019). 10 Efek Buruk Makanan Manis Pada Tubuh. Https://Www.Nibble.Id/. https://www.nibble.id/blog/10-efek-burukmakanan-manis-pada-tubuh/

Belinda, G. (2019). Kadar Gula Darah Normal dan Cara Mencegah Diabetes. Honestdocs. https://www.honestdocs.id/kadar-guladarah-normal

Kahn, M. (1994). Diabetes Data Set. UCI Machine Learning Repository. https://archive.ics.uci.edu/ml/datasets/diab etes

Kaur, H., \& Kumari, V. (2018). Predictive modelling and analytics for diabetes using a machine learning approach. Applied Computing and Informatics, $1-6$. https://doi.org/10.1016/j.aci.2018.12.004

Kavakiotis, I., Tsave, O., Salifoglou, A., Maglaveras, N., Vlahavas, I., \& Chouvarda, I. (2017). Machine Learning and Data Mining Methods in Diabetes Research. In Computational and Structural Biotechnology Journal (Vol. 15, pp. 104-116). Elsevier B.V. https://doi.org/10.1016/j.csbj.2016.12.005

Mukarromah, M., Martha, S., \& Ilhamsyah, I. (2015). PERBANDINGAN IMPUTASI MISSING DATA MENGGUNAKAN METODE MEAN DAN METODE ALGORITMA K-MEANS. BIMASTER, 4(3), $\quad$ 305-312. http://jurnal.untan.ac.id/index.php/jbmstr/a rticle/view/12425/

Pappada, S. M., Cameron, B. D., Rosman, P. M., Bourey, R. E., Papadimos, T. J., Olorunto, W., \& Borst, M. J. (2011). Neural network-based real-time prediction of glucose in patients with insulin-dependent diabetes. Diabetes Technology and Therapeutics, 13(2), 135-141. https://doi.org/10.1089/dia.2010.0104

Robertson, G., Lehmann, E. D., Sandham, W., \& Hamilton, D. (2011). Blood Glucose Prediction Using Artificial Neural Networks Trained with the AIDA Diabetes Simulator: A Proof-of-Concept Pilot Study. Journal of Electrical and Computer Engineering, 2011, 111.

https://doi.org/doi:10.1155/2011/681786

Sandham, W. A., Lehmann, E. D., Zequera Diaz, M., Hamilton, D. J., Tatti, P., \& Walsh, J. (2011). Electrical and computer technology for effective diabetes management and treatment. Journal of Electrical and Computer 
$\begin{array}{lcc}\text { Engineering, } & 2011, & 1-3 . \\ \text { https://doi.org/10.1155/2011/289359 }\end{array}$

Saputra, N., Adji, T. B., \& Permanasari, A. E. (2016). Analisis sentimen data presiden Jokowi dengan preprocessing normalisasi dan stemming menggunakan metode naive bayes dan SVM. Jurnal Dinamika Informatika, 5(1), 1-12.

http://ojs.upy.ac.id/ojs/index.php/dinf/artic le/view/113

Sarojini, B., Ramaraj, N., \& Nickolas, S. (2009). Enhancing the performance of libSVM classifier by kernel f-score feature selection. Communications in Computer and Information Science, $\quad 40, \quad 533-543$. https://doi.org/10.1007/978-3-642-035470_51

Soumya, D., \& Srilatha, B. (2011). Late Stage Complications of Diabetes and Insulin Resistance. Journal of Diabetes \& Metabolism, 02(09), 1-8. https://doi.org/10.4172/2155-
6156.1000167

Sun, S. (2013). A survey of multi-view machine learning. In Neural Computing and Applications (Vol. 23, Issues 7-8, pp. 20312038). $\quad$ Springer. https://doi.org/10.1007/s00521-013-13626

Waila, P., Marisha, S., Singh, V. K., \& Singh, M. K. (2012). Evaluating Machine Learning and Unsupervised Semantic Orientation approaches for sentiment analysis of textual reviews. 2012 IEEE International Conference on Computational Intelligence and Computing Research, ICCIC 2012. https://doi.org/10.1109/ICCIC.2012.651023 5

Wulandari, D., \& Subekti, A. (2019). Laporan Akhir Penelitian Mandiri: Prediksi Level Glukosa Pada Penderita Diabetes Dengan Support Vector Regression. 